\title{
SIMPLE WORD OF MOUTH OR COMPLEX RESOURCE ORCHESTRATION FOR OVERCOMING LIABILITIES OF OUTSIDERSHIP
}

\author{
Stoyan Stoyanov \\ University of Strathclyde \\ Richard Woodward \\ University of Edinburgh \\ Veselina Stoyanova \\ University of Strathclyde
}

Acknowledgments: The authors would like to acknowledge the insightful comments and suggestions of John Amis, Royston Greenwood, Omaima Hatem, Michael Hitt, Jonathan Levie, Volker Mahnke†, William Schulze, and two anonymous reviewers. The usual disclaimers apply. Corresponding author: Stoyan Stoyanov, University of Strathclyde Business School, Hunter Centre for Entrepreneurship, Sir William Duncan Building, 130 Rottenrow, Glasgow, UK G4 0GE Email: stoyan.stoyanov@strath.ac.uk 


\begin{abstract}
Drawing on the resource orchestration literature, we explore the processes by which transnational entrepreneurs offset the liabilities of outsidership they face in their host country. We show how these entrepreneurs' outsidership with respect to domestic business networks of the host country is compensated by their involvement in diaspora networks. Our second contribution lies in an extension of the resource orchestration framework, as we show that sequencing of resource orchestration processes is important for the implementation of the entrepreneurs' strategy for using their embeddedness within the diaspora network for enhancing their competitiveness, and can lead to lead to groupings of activities that differ from the groupings found in the original version of the framework.
\end{abstract}

Keywords: liabilities of outsidership; transnational entrepreneurs; resource orchestration 


\section{SIMPLE WORD OF MOUTH OR COMPLEX RESOURCE ORCHESTRATION FOR OVERCOMING LIABILITIES OF OUTSIDERSHIP}

\section{INTRODUCTION}

International business research shows that firms operating outside their home countries face additional costs of conducting business activities in a host country commonly described as liabilities of foreignness (LOF) - costs that native actors do not usually incur (Baik, Kang, Kim, \& Lee, 2013; Hymer, 1976; Kindleberger, 1969; and Zaheer, 1995). Most of the work on how firms cope with the liabilities of foreignness has focused on how companies develop or implement company-specific tangible assets (e.g. product innovations) that compensate for the liabilities they experience (Caves, 1971; Hymer, 1976; and Zaheer, 1995). However, low-visibility new business actors are highly likely to lack financial resources or any easily commercialized firm-specific advantages and therefore cannot offset the liabilities of operating abroad. Thus, this approach leads to a theoretical bias against the success of new business ventures. Observed reality is not consistent with such a bias, however, and in recognition of this, attention has more recently turned to the question of how firms experiencing LOFs but unable to compensate them with internal resources can access external resources for this purpose (see, e.g., Barnard, 2010), and our work makes a contribution to this line of research.

Another recent development in this area is the argument that the prime constraint in internationalization does not consist in liabilities of foreignness (related, e.g., to psychic distance) but rather in the liability of outsidership; i.e., a position outside relevant networks in a particular market (Johanson \& Vahlne, 2009). This shifts the focus from the competitive advantage of a given firm in isolation to its embeddedness. Relatively little is known about how small businesses actively manage their positions in the networks that facilitate their internationalization (Hilmersson 
\& Jansson, 2012), and this gap extends to the activities of transnational entrepreneurs (TEs). This study addresses that gap by examining the operations of TEs from Bulgaria in the UK, focusing on how these actors offset the liabilities of being outsiders to the domestic business networks of their British host country. Transnational entrepreneurs, as defined by Drori, Honig, and Wright (2009: 1001), are "entrepreneurs that migrate from one country to another, concurrently maintaining business-related linkages with their former country of origin and currently adopted countries and communities". TEs operating in the locus of ethnic diasporas (the context where links and ties are maintained) are an appropriate subject for researching how small businesses mobilize the resources of the diaspora networks for the purpose of reducing the liabilities of foreignness and outsidership. Looking at small companies and their intangible resources within the diaspora context (i.e. relationships and knowledge), as well as the way those resources are utilized, makes it possible to highlight the role of entrepreneurs in achieving market embeddedness. This is a response to the call by Drori et al. (2009: 1016-1017) for research into "the business and organizational model of TE, and [...] the factors, structures, institutions, and processes that shape them" and how "TEs dynamically engage in imposing, demanding, resisting, and altering forms and strategies of business creation and development, controlling and manipulating their respective environments."

This paper makes three contributions: First, we highlight the importance of operating within a diaspora network for realizing effective accumulation of resources, bundling of resources for competency building, and competency leveraging. Second, we provide an integrated orchestration framework that suggests how entrepreneurs utilize the processes of resource portfolio structuring (acquisition, accumulation, and divestment) and resource bundling (enrichment, stabilization, and pioneering) identified in the resource orchestration (RO) framework of Sirmon, 
Hitt, Ireland, \& Gilbert (2011) for the purpose of offsetting their liabilities of outsidership (LO) in a host country environment. Third, our findings extend the RO framework itself by demonstrating the role that the sequencing of the various processes plays in resource orchestration, showing how the sequencing of various processes may vary to respond to the particular conditions an entrepreneur is facing.

In the next section of this paper, we will discuss first the literature on the liabilities of and assets of foreignness and outsidership and second the resource orchestration framework that we utilize in our analysis. We then discuss methodological issues. This is followed by the presentation of our findings, and the final section contains a discussion of the findings and conclusions.

\section{THE LIABILITIES AND RESOURCES OF TRANSNATIONAL FIRMS}

\section{Liabilities of Foreignness and Outsidership}

The costs that constitute the LOF are due to the difficulties foreign actors face in attempting to efficiently manage country-specific knowledge sources and flows. Difficulties in communication and understanding are the principal causes of LOFs (Schmidt \& Sofka, 2009). LOFs translate into higher risks and uncertainty, greater frequency of business errors, and lower productivity (Lord \& Ranft, 2000), but most importantly difficulty in gaining access to, and managing, knowledge resources.

Network research has shown the importance of social and network capital in entrepreneurial companies, including (and perhaps especially) internationalizing ones (Birley, 1985; Nahapiet \& Ghoshal, 1998; Coviello, 2006; Johanson \& Vahlne, 2009). Social networks serve as channels of knowledge and information, which can promote the effective alignment of knowledge or practices (Podolny, 2001). Johanson and Vahlne (2009) have argued that the liabilities of foreignness are actually the liabilities of outsidership - that is, the fact that they are 
not embedded in the domestic business networks of the host country (Schmidt and Sofka, 2009, make a similar point, emphasizing access to host country customers). These challenges would apply to TEs as well, and if we accept the contention of Ostgaard \& Birley (1994) that personal networks are the most important resource of entrepreneurs, it is clear that overcoming the liability of being an outsider to the domestic business networks of the host country would be a matter of particular urgency for the TE. Drori et al. (2009) are clear that a key competitive advantage for TEs is constituted by their dual networks, encompassing both the home and the host country, but the host country networks must be built, and it is worth asking how this is done. In this context, new TE actors might capitalize on the opportunity to use the legitimacy that they are granted by fellow ethnic diaspora members based on cultural and social commonalities. Doing so allows TEs to reduce the potential friction between the host and home countries' cultures, which disrupts actors' market integration capacity and undermines legitimacy (Zaheer, 1995). The TE literature also points out that the liabilities that need to be overcome by TEs are of a peculiar nature, as they include the institutional constraints of both the home and host countries, as well as the achievement of embeddedness in both those environments (Drori et al., 2009; Yeung, 2002).

This leads us to ask what is an efficient way for TEs to acquire from this network that which they need to overcome the liabilities of foreignness and outsidership; that is, how to build a portfolio of knowledge to achieve alignment with the host-country market. And it is this portfoliobuilding that is the subject of the resource orchestration framework.

\section{The Resource Orchestration Framework}

The resources (social and non-social capital) at a firm's disposal have long been the subject of interest for scholars in various management-related disciplines, but there is a growing awareness that resource-related processes need to be examined as well (Kraaijenbrink, Spender, \& Groen, 
2010). As Hansen, Perry, and Reese (2004: 1280) observed, "what a firm does with its resources is at least as important as which resources it possesses". Sirmon et al. (2011) identify three sets of processes by which firms orchestrate their resources (see also Sirmon \& Hitt, 2003; Sirmon, Hitt, \& Ireland, 2007, and Sirmon, Gove, \& Hitt, 2008). These are:

- Structuring of the resource portfolio, which includes the acquiring (i.e., obtaining), accumulating (i.e., internal development) and divesting of resources;

- Bundling, or combining, of sets of capabilities in order to create new, or modify existing, capabilities; this includes the stabilizing (i.e., incremental improving), enriching (i.e., extending) and pioneering of capabilities, and

- Leveraging capabilities "to create value for customers and wealth for owners", which includes the mobilizing of capabilities (i.e., identifying those capabilities "needed to support capability configurations necessary to exploit opportunities in the market"), as well as the coordinating ("integrating identified capabilities into effective yet efficient capability configurations") and deploying of capabilities (Sirmon et al., 2011: 277).

In the research presented here, the resource orchestration framework proved to be of great value in analyzing the embedding of TEs in diaspora networks and the way this guides their efforts to overcome the liabilities of foreignness and outsidership. The resources with which we are concerned are ties within the diaspora network and the knowledge that flows into the TEs' businesses from those ties. Specifically, we will be concerned with how TEs enter the diaspora network, making initial ties with incumbents in the network (structuring, in the language of Sirmon et al., their portfolio of ties); then, with how they begin to deepen these ties by, for example, establishing their own value as partners for other network members (bundling), and finally, with 
how those ties are finally leveraged in order to gain the knowledge TEs needed to make their businesses viable in the host country environment.

The possible importance of sequencing in resource orchestration is hinted at by Sirmon et al. (2007), who note (p. 275) that "the resource management process is at least partially sequential in nature." Sirmon et al. (2011) do not explicitly deal with the sequencing of the various subprocesses. However, they do link various activities to phases of the enterprise life cycle (noting, for example, the importance of acquiring and accumulating resources in the start-up phase, and the importance of divesting them in the decline phase), and this has implications for sequence. These implications, however, remain undeveloped, and the authors suggest that this is an area in which further work is merited (p. 1408): "given that the resources available to a firm in the start-up phase can differ from resources available to mature firms, there is a need for research to understand how managers orchestrate the transition from one portfolio to a different yet more useful portfolio." One of the most important issues to be explored in this paper is how the sequencing of resource orchestration processes may vary as a result of the conditions facing an entrepreneur.

\section{METHODOLOGICAL APPROACH}

\section{Field of Observation and Data}

This is an exploratory, qualitative study of a group of 12 case companies operated by Bulgarian transnational entrepreneurs and located in London, based on a total of 63 semi-structured interviews with managers, employees and external stakeholders. London was selected as the geographical context of this study because, according to the 2011 labor force report of the UK Office for National Statistics, London was home to $46 \%$ of all self-employed foreign-born workers in the country. Moreover, Bulgarian entrepreneurs working in London number 4537, or 51.5\% of the total of 8798 in the UK (Centre for Entrepreneurs \& DueDil, 2014). The choice of the data 
context is justified by an important socio-political, as well as economic, event: Bulgaria's accession to the European Union in 2007. This event stimulated the economic and migratory exchange between the two countries of interest - the UK and Bulgaria - which spurred the emergence of a new wave of transnational entrepreneurial companies. All the businesses studied here were founded or became transnational at the time of, or following, Bulgaria's accession. As estimated by Zaheer and Mosakowski (1997: 461), it takes 15 years to "level the playing field" between foreign and local firms. Thus, Bulgarian entrepreneurs in London represent a diaspora community of transnational entrepreneurs engaged in the processes of reducing LO while this liability is still present.

The entrepreneurs studied were identified from a list of more than 130 companies operating in the UK, obtained from the British-Bulgarian Chamber of Commerce after an initial contact with Embassy of the Republic of Bulgaria. The group was further filtered by means of a survey that had the purpose of separating transnational entrepreneurs, who act as bridges between nations and cultures, from ethnic entrepreneurs (i.e., persons serving only a particular ethnic community), as well as making sure that the selected cases fulfil other selection criteria. These were that companies: (1) fall under the Drori et al. (2009) definition of the transnational entrepreneur cited in the introduction, (2) be considered SMEs, (3) be located in the Greater London area, and (4) engage in consulting services (as declared in their company profile). The reason for the decision to focus on consulting service providers was that we are particularly interested in knowledge resources.

The businesses identified in this manner were 2 to 10 years old and employed from 5 to 27 people. Of the selected companies, all but two are providers of high value-added services such as general business consulting, procurement, local search engine optimization, outsourcing, and 
business law consulting. The remaining two are specialist food and beverage retailers included in the research because, along with retailing, they engage in logistics consulting (e.g., securing suppliers or consulting on distribution in order to improve customer service). Because of the activity profile of the studied companies, their knowledge intensity is high.

To gather data, we used a combination of total number of 63 semi-structured interviews, observations and oral/life stories. The interviews were conducted in Bulgarian by the first author, who is Bulgarian, and the interview structure was designed for a series of 60-90 minute semistructured interviews. In each of the 12 companies studied, one interview was conducted with the owner (all of whom were males); these 12 interviews were then transcribed, coded, and analyzed. Further interviews with at least three employees of each company were conducted (for a total of 40 interviews with employees) to garner additional insights into the strategies engaged in by the various firms. The employees interviewed for this purpose were suggested by the owners. They held various positions but were all referred to by the owners as experienced professionals who are in the core of the companies' operations and active participants in the companies' development. These conversations tended to be rather informal and of varying length, and were always conducted following the interview with the owner, and in his absence. We also conducted interviews with 11 independent informants, including a consultant specializing in European subsidies and the consul of the Bulgarian Embassy in London, as well as business owners and other professionals approached during social events organized by the Bulgarian City Club in London and the Bulgarian Embassy in London.

\section{Data Reduction and Analytical Approach}

Observations were carried out by the first author during social events organized by the British-Bulgarian Chamber of Commerce, the Embassy of the Republic of Bulgaria, and individual 
actors' business meetings, making it possible to gain direct insight into the entrepreneurs' social representation strategies by observing how the entrepreneurs position themselves and initiate conversations, which was an important indicator regarding their strategies for embeddedness. Attending social events also led to 11 interviews, which were impromptu in nature, with actors from the entrepreneurs' environment, including officials from the Bulgarian Embassy, the director of the British-Bulgarian Chamber of Commerce, Bulgarian business professionals working for British and international corporations, consultants based in Bulgaria, and other members of the Bulgarian diaspora in London. The events attended took place in August and September of 2011 and included two monthly meetings of the Bulgarian City Club. This club has long-standing relationships with the Bulgarian Embassy and the Chamber of Commerce but is also open to business professionals working in British or multinational companies.

All interviews and field notes were transcribed and analyzed through narrative analysis. The analysis of an iterative and abductive nature, moving back and forth between the language used by the interviewees and a language employing the constructs of the relevant literature, as well as between the empirical material and new strands of theory that proved to be relevant as the research and analysis progressed. It was thus that we discovered the relevance of the resource orchestration framework to the processes in which we observed TEs to be engaged, not having initially adopted that perspective at the outset of the field work. The process of analyzing the data was divided into three stages.

First, in open coding, we created first-order categories on the basis of raw quotes from the interview material. Statements by the interviewees which described various events, actions, and perceptions in the evolution of their businesses were identified. This allowed us to identify commonalities in the narratives. These categories were initially coded by the first author, who had 
conducted the interviews, and were subsequently revisited by the other authors, who verified the fit between the quotes in question and the interpretations contained in the first-order categories.

Second, in axial coding we integrated the first-order categories into second-order themes. At this stage of the analysis, patterns in the data were identified which allowed us to isolate the processes made up by the various events and actions occurring in the development of the TEs' businesses. It was at this point that we discovered the relevance of the work by Sirmon et al. (2011) on resource orchestration ( $\mathrm{RO}$ ), observing that many of the processes identified there were also observed to be occurring in the developments we were analyzing, and essentially the second-order themes identified in our work correspond to the various RO processes.

In the final stage, we applied selective coding in order to aggregate the theoretical dimensions that emerged as fundamental for this study.

The step-by-step approach outlined above is exemplified by Figure 1, showing how we have conceptualized the analysis by dividing it into first-order categories (emerging from open coding), second-order themes (emerging from axial coding), and aggregate dimensions (emerging from selective coding).

Insert Figure 1 about here

\section{FINDINGS}

This section describes entrepreneurs' path from the moment of entering the UK as outsiders to the moment of being able to maneuver in the local business environment and realize their business objectives. This section illustrates the staged approach to gaining insidership in a foreign environment, as well as the processes and the tactics that facilitate the observed phases. Figure 2 
illustrates how each stage or phase is associated with certain strategies (which include the various elements of resource orchestration, from the model of Sirmon et al., 2011) as well as certain tactics employed by the TEs in order to implement these strategies. This section will discuss each of those phases in turn.

Insert Figure 2 about here

As shown below, the data indicates the gradually increasing influence of the diaspora community, which serves as a mechanism that facilitates not only the adoption of norms, codes of conduct, and applicable business practices, but also the development of context-relevant knowledge and capabilities.

\section{Outsidership}

Newly arrived transnational entrepreneurs from Bulgaria have difficulty accessing the local British business networks. The lack of belonging (i.e. their outsidership), goes beyond a mere unfamiliarity to local customs and social behavior. As shown in the quote below by Entrepreneur F, outsidership means difficulty to understand which of the skills, experiences and/or resources that the entrepreneur brings may result in performance advantages.

I wanted to form collaborations with some of the British competitors. I thought that the learning can be mutual but I received many rejections. All of them seemed concerned about working with me. I remember thinking that if I knew the reason why they were so afraid of me I would turn it against them and be successful.

This unawareness of their potential competitive advantages put TE in an unfavorable position, which causes hesitation and lack of confidence in their own potential. As a result of this, 
as explained by Entrepreneur D, the first phase of their business development is abundant with anxiety, turning points, identity crises and insecurity.

Being new to this country brought that hesitation. We were not known as a company so customers did not know whether we were any good. At one point, I started wondering whether I am any good.

Driven by the strong need to identify which of their assets may result in performance advantages, TEs desire to establish relationships with local business people in order to gain that insight from them. They believe that realizing this tactic will result in either affirmation of their entrepreneurial aspirations or negation, followed by entrepreneurial exit.

Simultaneously, signs of social and cultural anxiety continue to be present. Ethnic cultural events become an opportunity for TEs to counteract the social isolation that comes with their outsidership. As shown in the quote below by Entrepreneur $\mathrm{H}$, the need for cultural identity is intensified in the host-country.

I am well-traveled but it does not mean I don't get homesick. Wherever I go I look for ways to connect with compatriots. Also, of all the places I have been to, I have always felt best when there is an active Bulgarian community, which celebrates the Bulgarian identity.

We observe a discrepancy between the entrepreneurs' attempts to establish business relationships with host country locals (for the sake of gaining awareness of performance advantages) and attendance at diaspora cultural events (for counteracting social isolation). The former attempts have a business focus, but attendance at cultural events is not initially recognized as a tactic for achieving host country embeddedness. Later, however, as suggested by the following quote by Entrepreneur L, the TEs become aware that there are business individuals who support these Bulgarian social-cultural events. 
One of the first Bulgarian gatherings I attended was a folk music and dancing event. Being there made me feel very special for being a part of a noticeable community. At the same time, I felt very ordinary. My struggles were no different from these of other people when they first came. I was just one of the many people who tried to have things done in order to make a living. I wanted to hear other people's stories, especially from the successful business owners that everyone seemed to like for inviting those folk performers.

This new awareness gives rise to the staged approach to achieving insidership that we now present.

\section{Phase 1: Joining the Diaspora Cultural Circle}

The awareness of the domain where business and social needs can be served simultaneously leads TEs to create active sub-communities within the ethnic and cultural organizations they belong to. The system of knowledge "trading" within the diaspora network attracts newcomers seeking affirmation of their performance advantages. As a result of that development, TEs adopt a new set of tactics outlined by Entrepreneur A.

We get together for some major holidays [...] I help with providing some traditional food and beverages. I also go regularly to the events organized by the embassy. These events apart from proving ground for keeping the shared ethnic identity sometimes have the purpose of linking different business owners. [...]. I think it is good to get together with other likeminded individuals and just communicate. That helps the preservation of the ethnic identity but also facilitate other processes. I have worked with many of the people I meet in such events. It is absolutely amazing how small the world is. It has happened several times that I talk to somebody and I find out the brother or sister of that person is 
working for a logistics company, or is the manager in a food factory in Bulgaria. All these contacts come in handy.

The tactics that emerge from the quote are: help with providing some traditional food and beverages (i.e. supporting cultural events), keeping the shared ethnic identity (i.e. preserving cultural belongingness), and talk to somebody and I find out ... (i.e. gaining exposure to the ethnic community). Nevertheless, the entrepreneur focuses our attention on the desired processes that the tactics are employed for, namely linking different business owners and establishing contacts that come in handy.

Similar motivations, revealing the structure of the diaspora, are suggested in various statements - for example, in the following quote by Entrepreneur G.

When I want to meet fellow Bulgarians I know where to find them. The power of free banitsa [a traditional Bulgarian dish] is strong enough to attract from recent unemployed immigrants with no English speaking skills, to established Bulgarian businessmen. Of course, if you are not established yourself, then talking to the former is much easier than having a meaningful conversation with the latter.

\section{Phase 2: Joining the Community of Business Practice}

By functioning as an ecosystem that organizes and provides relevant events such as networking, training and mentoring, the diaspora community allows for the bridging of actors with similar entrepreneurial aspirations. The data reveal that the Bulgarian transnational entrepreneurs investigated here have a common strategy - network relatedness - for the purpose of identifying as-yet unrecognized competences that can potentially lead to performance advantages in the UK. While research was being conducted in diaspora social events, the first author had the opportunity to observe this strategy being implemented firsthand: in some situations his presence was even 
used as a tool in order to approach others, when, for example, he was introduced to others in the same way a British entrepreneur would be introduced to network incumbents. This behavior seemed to be a ritual for confirming network centrality. In table 1, we provide some representative quotes from our interviews illustrating how TEs acquire and enrich new knowledge as they build contacts within the diaspora community.

Insert Table 1 about here

Knowledge sharing and construction within the diaspora structures have the potential to provide entrepreneurs with focused market information that can confirm or refute the existence of performance advantages. Although access to market information allows them to compensate for their outsidership in the host country, it does not come easy. To reap the benefits of their business group access and to fully utilize this domain's community of practice (CoP) potential, newcomers employ specific tactics, namely absorbing norms and codes of conduct (i.e. meeting expectations), as well as managing the access to business knowledge they have from the home country. The following quote by entrepreneur F sheds more light.

I have volunteered to deliver a seminar and provide my knowledge on the business environment in Bulgaria. The first time I volunteered, and later they kept asking me if I would like to do another one for the people they invite. It takes up my time and energy, but I know it is worthwhile to make myself indispensable.

By acting as a gatekeeper of his home-country specific knowledge, the entrepreneur occupies a positon that helps him to be perceived as valuable for the community of business practice. This position facilitates the extraction of community knowledge for solving specific problems (e.g. 
adjustment purposes). Nevertheless, the mechanism by which the knowledge is acquired assumes a much broader significance: it becomes the main conduit for resource acquisition, the first stage of resource orchestration. The first knowledge acquisition activities in this sequence consist in acquiring and enriching knowledge (components of the structuring and bundling processes, respectively, in the resource orchestration model). As Entrepreneur C noted:

We [Diaspora members] are one team and we rely on each other's unique knowledge and experience. That combination of capabilities results in some very applicable ideas that help us not only finish a project but develop as an innovative company.

As the first author witnessed, diaspora social events serve as a forum for Bulgarians working in large multinational consulting companies to network with Bulgarian TEs to whom they hope to sell their services, and these consultants become important sources of managerial and other knowledge for the TEs. The following quote, from Entrepreneur I, illustrates in greater detail how, by hiring experts on a case-by-case basis or for a specified period, he brings external knowledge and capabilities into his business, which not only assists in satisfying customers' expectations, but also plays an important role in the creation of innovative business solutions and the company's competitive advantage.

If we do not possess the right level of expertise, we go to the market to buy some. Literally, we buy knowledge and proficiency. We cannot afford to keep a person who we need only twice a year. Moreover, the people we are looking for are experts in their fields and they are expensive. Expertise has always been highly valued so we purchase only part of the time of that specialist and build up the rest of the project based on the ideas and information we have acquired or that we possess in-house. Such free agent consultants often work for four or even five companies, advising them. It is inefficient, too expensive for a single 
company to afford such high ranked specialists, but we still benefit from the innovative thinking of such acknowledged experts rather than competing with them. In that way we can provide our clients with solutions for their business, solutions that would have cost them a fortune if they were to hire all the narrow experts that we communicate with.

The acquisition of knowledge is part of TEs' attempts to prepare a portfolio of resources. This process refers not only to obtaining a resource, but also realizing that a resource could be extracted from the entrepreneur's own transnational experiences and familiarity with home-host country duality. The enrichment of newly acquired knowledge occurs when it is used to extend current capabilities and make them relevant to the host-country environment. Both preparation processes (acquisition and enrichment) are gradual in nature and correspondingly motivated by the continuous association among network actors. And while both of them involve accessing and processing outside knowledge, both of these processes are motivated by purely internal perceptions of opportunities and strategies for exploiting them. The process of acquiring resources and enriching them via the diaspora mediation is illustrated by Entrepreneur J.

The field of commercial law consulting has been historically dominated by British companies. The law schools in the UK are known to be the best in the world, and this gives more credibility to native law professionals. I have employed [Bulgarian] people who have graduated here so I was able to benefit from this conception [...] However, at the beginning of their [careers], foreigners are less competitive in the local market if working alone. I assume that this is when most of them fail. However, these who can pass the stage of working alone $[\ldots]$ will increase their chances significantly and often progressively. By employing Bulgarians who have graduated from British law schools, the entrepreneur acquires a particular resource, which is important for his business success. Nevertheless, he states 
that foreigner entrepreneurs are less competitive in the British market if working alone. This suggests the mediating role of the diaspora, which not only linked him to desired human capital, but also enabled him to work collaboratively and thus increase his success chances significantly. An identical process of resource acquisition followed by mediated enrichment is shared by Entrepreneur A.

The thing that helped me survive is that I never thought I know everything and I am the best business person in the world. On the contrary, I knew that there is so much to learn, both for the business and for the environment in the UK. I relied heavily of the people who came to the UK earlier than me, they knew more and I wanted to learn from them. Being here for quite a long time has helped these other people to know the locals, their needs and expectations. They are also a good way to learn how the foreigners change when they live and work here. Immigrants have developed other expectations for the products and the services that they are offered, so this also was a new thing to consider.

This quote suggests that the entrepreneur has acquired knowledge on prospective customers' expectation. Yet, he is convinced that community members who came to the UK earlier are a good corrective, enriching the knowledge acquired by oneself.

\section{Phase 3: Gaining Network Embeddedness}

After joining of the community of practice within the business group, the newcomer entrepreneurs aim to establish stronger links to this community, which can translate into full utilization of the knowledge available in the community, as well as its absorption (i.e. integrating it into pre-existing schemas). In table 2 we provide quotes from our interviews illustrating the processes of accumulating and stabilizing knowledge that TEs engage in with greater intensity 
when they come to fully realize the value and potential contained in the diaspora business community.

Insert Table 2 about here

The following quote by Entrepreneur $\mathrm{K}$ demonstrates how the process of knowledge absorption is a socially formulated and mediated developmental process that is utilized for reaching specific entrepreneurial goals.

It was again my [Bulgarian] contacts who supported us ... through whom we had our first clients. I would not have been able to become part of the Bulgarian Association of Consultants in European projects if it were not thanks to the people who I know. Last but not least is the cooperation with the British consultancy that my contacts and connections pointed at as a viable opportunity.

The above quote reveals that the interaction with the diaspora mediates not only the entrepreneurs' understanding of the host country, but also the tools that they will deploy to engage in this environment. The knowledge absorption is employed via three tactics: 1) learning about the host country's rules and regulations; 2) verifying the relevance of deployed practices, and 3) verifying market knowledge. These are illustrated in the following quotes.

I started with the people I already knew and I did some consultations for their businesses. That built the routine and [...] procedures and rules within the company. I used my contacts for whom I worked at the beginning [in a] trial and error approach. I would not have been able to learn how to run a company with other customers as I would probably have lost them. By working with people whom I can describe as friends I had the flexibility to test 
different internal processes. This was slowing down the services they were getting but they could understand I appreciate their support. At the end they were happy with what I did for them and I am still thankful to them. (Entrepreneur J)

The above quote exemplifies how the diaspora relatedness enabled the entrepreneur to verify the relevance of the practices that his business employs. Serving people from his network while continuously establishing the routines of the company in a trial and error manner (in a sense, using a group of customers with whom mutual trust exists as guinea pigs) represents a recurring tactic. Another common tactic, again utilizing contacts from the diaspora, is explained in this quote by Entrepreneur C:

These acquaintances [with Bulgarians working in different sectors] oriented me in the business environment and also helped me understand the business regulations.

Further evidence that the desired knowledge resources are available within the network is provided by the following quote by Entrepreneur E.

The global crisis has also influenced the business, there are more regulations now and companies need to be more transparent when doing business. Many small companies in particular are not familiar with all the steps that they should take in order to meet the legal requirements and it is easy for them to make a wrong move and be liable. Given that change in the business environment, business lawyers are now more needed than before. We are familiar with the regulations changes and we help companies follow the rules and be successful.

The knowledge absorption is achieved via the accumulation and the stabilization of knowledge within the context of the identified tactics. Attempts to develop knowledge and align it with the host-country environment involve both the internal accumulation of that knowledge and 
its subsequent incremental improvement - which we refer to as stabilization - in association with more experienced TEs (accumulation and stabilization are components of the structuring and bundling processes in the resource orchestration model, respectively).

The accumulation of the knowledge that enables TEs to evaluate host-country rules and regulations, internally developed business practices, and other market knowledge, is followed by its subsequent stabilization through the mediating role of the diaspora environment. The diasporamediated action is not a default function of the network, but a process that needs to be enabled. The enabling factor here is a remarkable change in their perspective regarding the importance and benefits of a collaborative approach. This change in perspective, which we refer to as a paradigm shift, is illustrated by this comment by Entrepreneur K:

What I have in common with other entrepreneurs in the Diaspora is the vision that cooperation is beneficial. It is not only beneficial for my own initiatives, but also for the business of other partners. I admit that it took me some time to realize and start appreciating the functionality of that idea. I tried hard to understand what is going on here and how business is conducted. Nobody tells you that sharing is actually good in the long run. Of course, you get some signs from people, but during the very first steps you are on your own and getting your orientation [perspective] right is crucial.

When this happens, the orientation of TEs becomes highly cooperative, and they become ready to share knowledge and reciprocate. This readiness to reciprocate is the most important characteristic distinguishing the phases following the paradigm shift from those preceding it. However, as indicated by Entrepreneur K, this is not automatic. Adopting this cooperative approach requires the entrepreneur to first move beyond the shared values and culture within the diaspora network to the knowledge accumulation and stabilization processes referred to above. 
Once this paradigm shift has occurred, the TEs' approach to the utilization of outside knowledge changes fundamentally; having previously been highly individualistic, it now acquires a more collective character. The following quote by Entrepreneur L illustrates the transition and its subsequent influence on business development.

I benefited a lot from others' contacts and networks and others have benefited from mine. It takes more to entrust someone with your contacts than just trying to help by using own time and knowledge. I started to do this for others and this drove the company to progress. Even now, I am still dependent on these networks when doing business. This gave us the boost to become known in the market. What is the purpose of having abilities if nobody sees them?

As implied in the quote below by Entrepreneur I, some resources (e.g. knowledge, skills, reputation, etc.) may be difficult to simply acquire, so it is necessary to accumulate them (i.e., develop them internally, but with the assistance of other members of the diaspora network). Accumulation, which denotes the development of internal organizational facilitators or organizational structures that operate with the new knowledge, allows firms to create unique resource portfolios.

We formed the company and began offering consultations on business development and research on business financing, the development of business projects and management of business projects. At a later stage we added other functions such as analysis of European directives and regulations about business project proposals and fund management and company growth advices. Another branch which we have created concentrates on the organization of seminars, conferences and courses for company managers. 
The quote illustrates a sequence of events: first, offering a rather limited number of services, followed by the offering of more services and functions at a later stage. The entrepreneur has previously discussed the positive business implication of operating within the diaspora, which suggests the mediating role of the network. The expansion of the company's portfolio is driven by two processes: First, the internal development of the initial services, which were embedded in the company's operations, and second, the operationalization of existing resources to serve a new market context (e.g., moving from project development to expertise in developing European project proposals).

The knowledge thus accumulated often requires adaptation in order to fit the new market context (or the host-country institutional, business and social environment). This refinement takes place during the process of stabilization, triggered by the encounter between the transnational business unit and the communities of practice within the diaspora network. After experiencing the paradigm shift that leads diaspora entrepreneur to embrace the practice of reciprocity, they recognize the network's facilitative functions in the stabilization of their accumulated (i.e. internally developed) knowledge. Along with general incremental improvements to existing capabilities, stabilization encompasses the verification of prior knowledge (for example, of markets) and practices (in various areas of management and production). As Entrepreneur H noted: They [ideas and gathered knowledge] need to be tested either through practice or through other people's experience before we rely on these ideas. Although I might rely on the person who gives me the idea, I do not rely on every idea I hear but start testing it by planting the idea in conversations with other people to see what their opinion is.

\section{Phase 4: Insidership}


The final cycle of resource orchestration involves two further processes. First, diasporaenriched or -stabilized knowledge that does not function in the expected manner must be divested. When resources acquired earlier do not live up to the entrepreneurs' expectations, divesting them may be required for the development of new, more market efficient capabilities to become possible. In table 3 we provide quotes from our interviews illustrating the processes of divesting old, and pioneering new, knowledge observed among the TEs studied here after they had become fully-integrated members of the diaspora community.

Insert Table 3 about here

In the following quote, Employee F1 explained not only the need to divest obsolete knowledge, but how diaspora network contacts can help in this process:

We work in the IT sector, so you can imagine that we continuously need to learn about new technological advancements and to adapt by opting out obsolete business practices and technology and introducing more efficient ones. Staying close to our [diaspora] network helps us to recognize the moments when we need to do these changes.

The gap created by divestment of knowledge is filled by knowledge creation activities carried out jointly with other diaspora members (pioneering). At this point the knowledge acquisition orientation (observed in the preparation and the paradigm shift cycles) is replaced by a knowledge creation orientation. The change leads to a higher demand for the managerial acumen necessary for pioneering activity. The interaction between the divestment and pioneering processes and their overall relatedness to the preparation and the paradigm shift cycles of integration is illustrated by the following comments by Entrepreneur B: 
It can be even discouraging at times. You spend time to adapt, prepare, meet the right people and learn about what is it to succeed here and very often only to understand that what you have is not enough, or even worse, it cannot work here although you have been told it should. Then you either quit or shake off the fear thoughts along with the things that simply do not work.

Prompt: Can you provide an example?

One approach that did not quite work is the idea for having a sample portfolio of our previous works to highlight our marketing services. Small local companies who we regard as imperative clients were simply not buying it. It was not the culture this time, we already knew the environment. Then a fellow business owner [compatriot] suggested that small companies probably feared that we are using the sample portfolio for everyone so they do not get anything different from their competitors. Both of us left that practice and did something risky. My company started giving out personalized marketing advice to prospective clients and told them that no matter whether they end up using our services they can use the materials free of charge because we created them for their companies. This just works better for small companies in his and my industry sectors.

We gained the recognition of these business owners; some expressed desire to work with us on more significant projects, or whole campaigns. This is where the business comes from. Others accepted the gift but did not want to engage in business with us. However, these people became more helpful later. (Entrepreneur B)

In this quote the entrepreneur realized that despite going through the diaspora-assisted preparation and paradigm shift cycles of integration, occasionally what you have is not enough or it cannot work here although you have been told it should. This shows that the diaspora-assisted 
mechanism for developing a portfolio of knowledge aligned with the host-country environment does not always operate flawlessly. It appears inevitable that at some point the preparation and paradigm shift cycles will fail to deliver the anticipated level of performance advantages. This could be due either to the specificity of the recipient venture's business operation or to the limited scope of the knowledge available within the diaspora. Entrepreneurs' awareness of the confines of the network-assisted host-country market alignment motivates them to initiate their business activities, following the process of divestment of the ineffective knowledge and pioneering of its functional substitute.

\section{DISCUSSION AND CONCLUSION}

The resource orchestration framework was developed to deal with what Wright, Clarysse, \& Mosey (2012: 922) have referred to as "a lack of understanding of how resources and capabilities are acquired and configured to achieve growth." In this paper we have been concerned with resources on one hand and with liabilities on the other: the liabilities faced by a distinctive group of foreign entrepreneurs who, in their quest to gain access to the domestic business networks of the host country, find themselves on the outside looking in, and the resources that at least initially they are not sure they have and that they have difficulty even identifying. What we have seen is that discovering and entering a network of their fellow countrymen becomes not only a resource for gaining access to other external resources - including both the domestic host country networks and the knowledge and experience of other members of the diaspora - but also a cognitive tool for recognizing the value of the assets and resources they themselves already possess.

When TEs experience difficulties in becoming insiders in the domestic host country networks, they find that they can compensate for this by becoming insiders in the diaspora network. This may provide them with access to knowledge and resources of incumbents in that network that 
are at least as valuable as those they would gain by entering domestic networks, but may also help them to gain access to the domestic networks when more senior diaspora network incumbents are in a position to make the right introductions. This, in turn, firmly establishes them in the unique bridging positions that characterize the transnational entrepreneur.

We see these findings as an advancement of the literature concerned with the difficulties that internationalizing companies experience (Cuervo-Cazurra, Maloney, \& Manrakhan, 2007; and Madhok \& Keyhani, 2012), as well as a contribution to the international business literature dealing with the liabilities of foreignness (Hymer, 1976; Zaheer, 1995) and outsidership (Johanson and Vahlne, 2009). On the latter, we believe we have provided evidence that at least in the case of TEs Johanson and Vahlne's (2009) framing of the liabilities foreign companies face in their host countries as liabilities of outsidership vis-à-vis domestic business networks rather than as liabilities of foreignness per se makes sense. Additionally, we have shown how, at least in the peculiar circumstances of the TE, diaspora networks can be utilized to overcome the liabilities of outsidership (by substituting one form of insidership for another, and then by leveraging the former to gain the latter) - a finding that we believe has important and useful implications for business practice.

Another contribution consists in a model that builds upon the resource orchestration framework developed by Sirmon, Hitt, Ireland, and Gilbert (2011) and which, moreover, adds to their work a sequential element. The model illustrated in Figure 2 shows how resource procurement processes (acquisition, accumulation, and divestment) and configuration processes (enrichment, stabilization, and pioneering) can be utilized for the development of competencies relevant to the host country. Furthermore, we see that the way these processes play out over time allows us to group them into a sequence punctuated by three key events, which we refer to as 
preparation, paradigm shift and initiation. We will now examine this sequence of events in processes in more detail.

Becoming acquainted with the diaspora. As shown in our findings, the initial experience of outsidership for the TEs often consists in a kind of disorientation in the new environment, in which they not only lack contacts (and may even experience failure in their attempts to reach out to British businesspeople) but also confidence about which, if any, of their resources and capabilities might prove useful there. This combination of loneliness and insecurity provides the initial impetus to explore the diaspora community, initially by attending cultural events.

Entering a community of practice. As their involvement with the diaspora community on the cultural level intensifies, the second phase of diaspora networking begins, as the TEs become aware of, and narrow their focus to, the business contacts within the community. The cultural events become a way of getting one's foot in the door, of getting introduced to, and opening conversations with, more senior incumbent members of the community - opportunities they would be much less likely to enjoy with British businesspeople. At this point, the diaspora could be conceived as two concentric circles. The outer circle corresponds to the culture group, i.e. a domain that readily accepts individuals due to their normative cultural belongingness and ethnic origin. That circle hosts the inner circle - the business group, i.e. a domain occupied by more established to the host-country business owners and professionals. From the perspective of TEs who are new to the network, the business group is a more exclusive circle, the association with which is not readily available for mere participants in cultural events. Nevertheless, the two domains of the same diaspora network are linked by all members' mutual appreciation of culture. It is exactly this link that new TEs exploit to gain access to the business group, a functional community of business practice. The access is endorsed upon the realization of the tactics 
mentioned earlier, namely, resourcing cultural events, acclaiming cultural belongingness, and gaining exposure to the ethnic community.

Preparation. Once acquaintances have been made, the TEs who are new to the network must begin to gain the trust of the incumbents in order to access the valuable knowledge that they have. In terms of the resource orchestration framework, this is the phase in which the acquisition and enrichment of knowledge occurs, enrichment being a part of the absorption of knowledge in which it is adapted to the needs of the user who has acquired it.

Paradigm shift. The interview material captured a psychological moment in which TEs have a sudden insight about the role that the diaspora can play in the development of their businesses, as well as of the role that they themselves play. They describe this as a shift from a perception of business success in highly individualistic terms to seeing it as more of a collective endeavor. This involves a high degree of appreciation for mutuality as the basis of trust within the community. In resource orchestration terms, accumulation and stabilization of the knowledge gained from contacts within the network occur at this point; in other words, the knowledge gained is subject to further development and incremental improvement within the TE's business.

Initiation. At this point the TEs in question have become established members of the diaspora business community, and they may begin divestment of some of the knowledge that they have gained as a result of interaction with the diaspora community but which has not proved its value in the context of their businesses, as well as pioneering new knowledge - that is, becoming innovators in their own right, and thus repositories of knowledge that will be valuable not only to their fellow incumbents in the network but also to a new generation of arriving newcomers.

Our sequencing approach causes the activities to be grouped differently than in the original RO model, so that, for example, acquisition (which belongs to structuring) and enrichment (which 
belongs to bundling) appear together in our preparation phase; accumulation (structuring) and stabilization (bundling) appear together in the paradigm shift phase, and divestment (structuring) and pioneering (bundling) appear together in the initiation phase. In this way, what we see as sequencing can also be seen as synchronization - which Sirmon et al. (2011) refer to numerous times - from the point of view of the original model, since we see structuring and bundling processes being synchronized with each other.

Limitations. The replicability of this study's findings in other Diaspora settings is limited due to the nature of the employed methodology. The natural setting in which ethnography takes place impedes the control over external variables, which might hinder replication. Future research may address this limitation by testing the reliability of the findings, and in particular the relevance of the proposed integration framework in other contexts.

Policy and managerial implications. The managerial implications of the resource orchestration model are extended by the demonstration of how sequencing of orchestration activities can correspond to the particular needs that are being met as an enterprise and its networks co-evolve. Managers and entrepreneurs would do well to be sensitive to the importance of sequencing in their networking activities. In the policy area, we are intrigued by the implications of the "eureka" moment experienced by entrepreneurs, which we refer to as the paradigm shift, in which they become fully aware of the importance of their contacts and those contacts' knowledge for the growth and development of their businesses. A significant awareness barrier is clearly being overcome here, and it is likely that programs targeted at promoting entrepreneurship could achieve important gains by helping potential and beginning entrepreneurs understand the benefits of looking beyond an individualistic approach to business development. 
Future research. We believe that the temporal elements of the resource orchestration framework are worth further investigation. As noted above, Sirmon et al. (2011) have raised the possibility that enterprise life cycles could significantly impact the character of resource orchestration in each particular cycle, and have called for research on this. They also refer frequently to synchronization, and feedback loops (Sirmon et al., 2007), both of which introduce further temporal elements. Feedback, sequence, and synchronicity are only some of the elements of temporality that could be explored further in work on the resource orchestration framework. One area we think particularly worthy of further attention is the question of the various logics that may lead to different groupings of resource orchestration processes in different sequences, depending on the variations in the situation (ranging from differences in the diaspora group in which entrepreneurs are involved to differences in the types of entrepreneurship or of companies being studied).

In conclusion, this paper contributes to the debate on the liabilities of foreignness versus the liabilities of outsidership by showing the relevance of the latter for transnational entrepreneurs, as well as how they use insidership in diaspora networks as a counterweight to their outsidership with respect to the domestic business networks of the host country. It also contributes to the resource orchestration literature by demonstrating the importance that the sequence of orchestration activities can assume, thus pointing to opportunities for further research regarding the temporal aspects of resource orchestration. 


\section{REFERENCES}

Baik, B., Kang, J., Kim, J., \& Lee, J. 2013. The liability of foreignness in international equity investments: Evidence from the US stock market. Journal of International Business Studies, 44: 391-411.

Barnard, H. 2010. Overcoming the liability of foreignness without strong firm capabilities — the value of market-based resources. Journal of International Management, 16: 165-176.

Birley, S. 1985. The Role of Networks in the Entrepreneurial Process. Journal of Business Venturing, 1: 107-117.

Caves, R. 1971. International corporations: the industrial economics of foreign investment. Economica, 38(149): 1-27.

Centre for Entrepreneurs \& DueDil. 2014. Migrant Entrepreneurs: Building Our Businesses, Creating Our Jobs. Retrieved from www.creatingourjobs.org/data/MigrantEntrepreneursWEB.pdf.

Corley, K. \& Gioia, D. 2004. Identity ambiguity and change in the wake of a corporate spin-off. Administrative Science Quarterly, 49: 173-208.

Coviello, N. 2006. The network dynamics of international new ventures. Journal of International Business Studies, 37: 713-731.

Cuervo-Cazurra, A., Maloney, M., \& Manrakhan, S. 2007. Causes of the difficulties in internationalization. Journal of International Business Studies, 38: 709-725.

Drori, I., Honig, B., \& Wright, M. 2009. Transnational Entrepreneurship: An Emergent Field of Study. Entrepreneurship: Theory and Practice, 33: 1001-1022.

Hansen, M., Perry, L. \& Reese, C. 2004. A Bayesian operationalization of the resource-based view. Strategic Management Journal, 25: 1279-1295. 
Hilmersson, M., Jansson, H. 2012. International network extension processes to institutionally different markets: Entry nodes and processes of exporting SMEs. International Business Review, 21: 682-693.

Hymer, S. 1976. International operations of national firms: A study of foreign direct investment. Boston: MIT Press.

Johanson, J., \& Vahlne, J. 2009. The Uppsala internationalization process model revisited: from liability of foreignness to liability of outsidership. Journal of International Business Studies, 40: 1411-1431.

Kindleberger, C. 1969. American Business Abroad. New Haven: Yale University Press.

Kraaijenbrink, J., Spender J., \& Groen, A. 2010. The resource-based view: A review and assessment of its critiques. Journal of Management, 36: 349-372.

Lord, M., \& Ranft, A. 2000. Organizational learning about new international markets: exploring the internal transfer of local market knowledge. Journal of International Business Studies, 31: $573-589$.

Madhok, A., \& Keyhani, M. 2012. Acquisitions as entrepreneurship: asymmetries, opportunities, and the internationalization of multinationals from emerging economies. Global Strategy Journal, 2: 26-40.

Nahapiet, J., \& Ghoshal, S. 1998. Social capital, intellectual capital, and the organizational advantage. Academy of Management Review, 23: 242-266.

Ostgaard, T., \& Birley, S. 1994. Personal Networks and Firm Competitive Strategy-a Strategic or Coincidental Match? Journal of Business Venturing, 9: 281-305.

Podolny, J. 2001. Networks as Pipes and Prisms of the Market. American Journal of Sociology, 107: 33-60. 
Schmidt, T. \& Sofka, W. 2009. Liability of foreignness as a barrier to knowledge spillovers: Lost in translation? Journal of International Management, 15: 460-474.

Sirmon, D., \& Hitt, M. 2003. Managing resources: Linking unique resources, management, and wealth creation in family firms. Entrepreneurship Theory and Practice, 27: 339-358.

Sirmon, D., Gove, S., \& Hitt, M. 2008. Resource Managing in Dyadic Competitive Rivalry: the Effects of Resource Bundling and Deployment. Academy of Management Journal, 51: 919935.

Sirmon, D., Hitt, M. and Ireland, R. 2007. Managing Firm Resources in Dynamic Environments to Create Value: Looking Inside the Black Box, Academy of Management Review, 32: 273292.

Sirmon, D., Hitt, M., Ireland, R., \& Gilbert, B. 2011. Resource Orchestration to Create Competitive Advantage: Breadth, Depth, and Life Cycle Effects. Journal of Management, 37: 1390-1412.

Wright, M., Clarysse, B. \& Mosey, S. 2012. Strategic entrepreneurship, resource orchestration and growing spin-offs from universities. Technology Analysis \& Strategic Management, 24: 911927.

Yeung, H. 2002. Entrepreneurship in international business: An institutional perspective. Asia Pacific Journal of Management, 19: 29-61.

Zaheer, S. 1995. Overcoming the liability of foreignness. Academy of Management Journal, 38: $341-364$.

Zaheer, S., \& and Mosakowski, E. 1997. The dynamics of the liability of foreignness: A global study of survival in financial services. Strategic Management Journal, 18: 439-463. 
Table 1

Preparation Cycle: Acquiring and Enriching Acquired Knowledge

\begin{tabular}{|c|c|}
\hline $\begin{array}{l}\text { Label (first-order } \\
\text { categories) }\end{array}$ & Representative Quotes \\
\hline $\begin{array}{l}\text { 1. Overcome social } \\
\text { disorientation }\end{array}$ & $\begin{array}{l}\text { "These [diaspora] acquaintances oriented me in the business environment and helped me understand } \\
\text { the business regulations." (Entrepreneur C) } \\
\text { "I started advertising the company both in a personal but also in a public manner. I announced the } \\
\text { website to many ethnic centers, communities, clubs, the embassy. I used the Bulgarian newspapers as } \\
\text { well. Everything that I could think of. It worked and I am grateful to everyone who supported me." } \\
\text { (Entrepreneur A) } \\
\text { "It is different when having the support of a greater, not only numerous but also influential, group of } \\
\text { people who have already established themselves in the foreign market. The people we have met, } \\
\text { because of our engagement with the Bulgarian community and the organizations we participate in, } \\
\text { have used their contacts on several occasions to get us access to some retailers." (Entrepreneur H) } \\
\text { "I am with the company from day one. I ... we have learnt a lot not only from our own experience but } \\
\text { from the experience of other entrepreneurs within our [diaspora] community ... even what may seem } \\
\text { so simple and straightforward now, such as gaining an understanding of the financial, banking system } \\
\text { for managing our company accounts." (Employee G1) }\end{array}$ \\
\hline $\begin{array}{l}\text { 2. Realize disrupted } \\
\text { market integration } \\
\text { capacity }\end{array}$ & $\begin{array}{l}\text { "What many immigrant entrepreneurs find difficult to realize before they start business is that even } \\
\text { if you have a clear plan of action that will bring value to the company and the stakeholders in this } \\
\text { country [the UK], being a foreigner is a significant barrier and challenges the survival of even the } \\
\text { most altruistic business venture. Everyone should be clear about the risks and consider them." } \\
\text { (Entrepreneur K) } \\
\text { "A couple of years ago, down memory lane, the hardest thing was to secure good suppliers as we } \\
\text { were new to the market. We did not have enough knowledge before establishing connections with } \\
\text { the Bulgarians [from the diaspora] so everyone was trying to charge us much higher than they would } \\
\text { charge someone who is already present." (Employee A1) }\end{array}$ \\
\hline
\end{tabular}




\begin{tabular}{|c|c|}
\hline & $\begin{array}{l}\text { "The majority of entrepreneurs coming from abroad have most of their contacts in the home country } \\
\text { and it is difficult for us to establish equally reliable contacts in the foreign country, it just takes time. } \\
\text { For that reason most of the companies created by foreigners are connected to the home country and } \\
\text { the available contacts and resources there." (Entrepreneur J) } \\
\text { "They [entrepreneurs coming from abroad] are certainly more vulnerable due to the price factor." } \\
\text { (Entrepreneur F) }\end{array}$ \\
\hline $\begin{array}{l}\text { 3. Gain knowledge } \\
\text { regarding intangible } \\
\text { barriers }\end{array}$ & $\begin{array}{l}\text { "That kind of information [decision-support information] is very, very important. I am always } \\
\text { looking for such information but sometimes the decision has to be made when there is only highly } \\
\text { limited information. Not reacting is sometimes even worse than when reacting in a wrong way." } \\
\text { (Entrepreneur A) } \\
\text { "Examining the strategies of other companies operating in the same sector and getting to know what } \\
\text { is behind them, whether they are successful or not ... The faster we have such information the faster } \\
\text { we can react to this opportunity and increase both our chances of signing the deal and the chances of } \\
\text { becoming more competitive against other marketing companies." (Entrepreneur B) } \\
\text { "A major part of the success has been hard work, of course, but also how to talk, and most } \\
\text { importantly whom to talk to ... A small hint about the market dynamics makes a huge difference. } \\
\text { This is particularly relevant when we are given short notice to reach a given target." (Employee G1) } \\
\text { "Information is seldom straightforward, sometimes it is quite dubious and it can only be decoded } \\
\text { through other sources. That is why we do not just take everything at face value. We compile } \\
\text { information, contextualize it, and analyze it, and only then do we act. Based on what we have found } \\
\text { we rate companies and their products, or services if we conduct an analysis of selected distributors, } \\
\text { we rank potential options and decide which is the most beneficial for our clients." (Entrepreneur C) }\end{array}$ \\
\hline $\begin{array}{l}\text { 4. Absorb norms, } \\
\text { codes of conduct } \\
\text { (reflexivity) }\end{array}$ & $\begin{array}{l}\text { "I let them know that I am a team player and they can expect reciprocal activities from me. It is } \\
\text { important to be supportive when they need it; this shows that I do not forget, which will help for the } \\
\text { future." (Entrepreneur C) } \\
\text { "The thing that helped me survive is that I never thought I know everything and I am the best } \\
\text { businessperson in the world. On the contrary, I knew that there is so much to learn, both about the }\end{array}$ \\
\hline
\end{tabular}




\begin{tabular}{|c|c|}
\hline $\begin{array}{l}\text { business knowledge and } \\
\text { opportunities, thus trying to } \\
\text { move away from the } \\
\text { periphery of the network by } \\
\text { better relating to established } \\
\text { social and business norms }\end{array}$ & $\begin{array}{l}\text { business and the environment in the UK. I relied heavily on the people who came to the UK earlier } \\
\text { than me, they knew more and I wanted to learn from them." (Entrepreneur A) } \\
\text { "By being part of this club, I am given the opportunity to mingle with such a crowd and exchange } \\
\text { ideas and build inter-organizational bridges. The same opportunities are present in the other } \\
\text { organizations that I participate in. The difference is the direction of the organizations and the } \\
\text { proximity to a certain group of people. The Association of Consultants, for example, gives us the } \\
\text { links to competitors. It is a formal ground for collaboration, something that is hard to achieve among } \\
\text { competitors." (Entrepreneur L) } \\
\text { "The Bulgarian wine club has a history of operations in different foreign markets - Germany, } \\
\text { Poland, the US, and others - and they have a lot of experience of doing business abroad. We are not } \\
\text { really members of this club because it is a club for wine manufacturers and they try to overcome } \\
\text { middlemen like us, so they are our competitors, but we still have good relations with some of the } \\
\text { members, so we learn from them about doing business." (Entrepreneur H) }\end{array}$ \\
\hline $\begin{array}{l}\text { 5. Extract resources } \\
\text { from personal } \\
\text { experience }\end{array}$ & $\begin{array}{l}\text { "The collaboration within the diaspora and the interaction with other members help me not only to } \\
\text { acquire high quality new knowledge at a fraction of its value, but also to achieve better use of the } \\
\text { available knowledge. New use of already existing information is as valuable as new information, } \\
\text { with the only difference that I am less dependent on others, as I carry it with me when crossing } \\
\text { borders. [...] For that reason, it is important to link with others that have different point of view and } \\
\text { might enrich the idea generation process by either spotting a new application of my knowledge or } \\
\text { helping me to build on what I have picked up." (Entrepreneur D) } \\
\text { "Moreover, being a mentor to a few people also helped me, it helped me to build links to the } \\
\text { younger groups. ... I constantly try to meet new people and share with them what I do and what I } \\
\text { aim at. In the long term this also helps; they introduce me to different people, from Bulgaria mainly, } \\
\text { who have a business interest in my company." (Entrepreneur A) } \\
\text { "As a marketing company, marketing ourselves is inevitable. So we participate in knowledge } \\
\text { exchange seminars as it is a way for others to recognize us as reliable company that has strong } \\
\text { connection with the market in which it operates. Giving some free advice, focusing company } \\
\text { managers on potential pitfalls and unique characteristics of the market enhances our image as a }\end{array}$ \\
\hline
\end{tabular}




\begin{tabular}{|c|c|}
\hline & $\begin{array}{l}\text { company that cares about their success. When they trust us more, they want to work with us more } \\
\text { closely. This is the beginning of the mutual business." (Entrepreneur B) } \\
\text { "I had previous experience working with suppliers in the wine business both in the UK and Bulgaria. } \\
\text { This has been quite handy when we started working together with [name anonymised] and we } \\
\text { needed to reach clients and suppliers in London and the UK in general." (Employee/ Business } \\
\text { partner H1) }\end{array}$ \\
\hline $\begin{array}{l}\text { 6. } \begin{array}{l}\text { Engage in efficient } \\
\text { management of the } \\
\text { country-specific } \\
\text { knowledge sources } \\
\text { and flows }\end{array} \\
\text { Description: Gaining } \\
\text { awareness of who is who in } \\
\text { the network and developing } \\
\text { ability to link to key business } \\
\text { contacts within the diaspora. } \\
\text { Social proximity promotes } \\
\text { the upgrading of capabilities }\end{array}$ & $\begin{array}{l}\text { "Individuals, when alone, are limited in their reasoning, I am not an exception. I need cooperation } \\
\text { for some matters. [...] Many companies experience difficulties at the beginning, but I think [...] } \\
\text { establishing a company is like a marathon, and the finish line should be the time when the company } \\
\text { opens and starts operating. If you want to participate in a marathon, you will not wait until the last } \\
\text { moment and start preparing immediately before the race. It takes a lot of hard work, planning, } \\
\text { consideration and talking to the right people." (Entrepreneur E) } \\
\text { "Getting along with my mentors helped me to become more familiar with everything here ... In that } \\
\text { way I communicate to people from many places. But I also travel a lot, communicate to my business } \\
\text { links in Bulgaria, exchange ideas and information. Being active inside and outside the community } \\
\text { increases trust and reputation. It is so different from doing business the straightforward way, [but] I } \\
\text { believe this is the right way." (Entrepreneur A) } \\
\text { "We use our knowledge about the local market and that allows us to benefit from the activities } \\
\text { taking place on an international level. At the same time if we have clients who would like to do the } \\
\text { same in the UK, we refer them to the other company, which has more knowledge and connection in } \\
\text { the foreign environment. In any of these cases we have financial benefit from that cooperation." } \\
\text { (Entrepreneur K) }\end{array}$ \\
\hline
\end{tabular}


Table 2

Paradigm Shift Cycle: Accumulation and Stabilization of Knowledge

\begin{tabular}{|c|c|}
\hline $\begin{array}{c}\text { Label (first-order } \\
\text { categories) }\end{array}$ & Representative Quotes \\
\hline $\begin{array}{l}\text { 7. Decrease cultural } \\
\text { distance by learning } \\
\text { host country's rules } \\
\text { and regulations }\end{array}$ & $\begin{array}{l}\text { "It is a never-ending cycle, and in order to be prepared we need to know what is relevant to the } \\
\text { specific environment; this helps in determining how to act. Our connections and daily } \\
\text { communication help in knowing new tendencies, changes in the business environment, changes in } \\
\text { the legal environment that subsequently influence the business." (Entrepreneur I) } \\
\text { "I would call it a challenge instead because I refer to something as a problem when there is } \\
\text { something more serious. The challenges were related to adapting to the new business environment } \\
\text { and being introduced to new people. Also, I had to understand all the regulations, which took some } \\
\text { time." (Entrepreneur C) } \\
\text { "We allocate the tasks carefully depending on everyone's specialty. We have hired two Bulgarians } \\
\text { and two British, all of them very skillful people. They have helped us to finish some projects and we } \\
\text { knew they are reliable so we have hired them after they graduated. The British people are not only } \\
\text { working on different marketing campaigns, they are also representatives of the business whenever } \\
\text { we try to approach a British company. In that way they believe us more, they feel that we are closer } \\
\text { to them and can better understand their expectations." (Entrepreneur B) } \\
\text { "There is an initial culture shock in the beginning, but being part of the [diaspora] community, has } \\
\text { helped us a lot in understanding both the cultural and business differences, sometimes just through a } \\
\text { simple talk. I will never forget the first time my manager sent me to negotiate a deal. The } \\
\text { counterpart repeated a couple of times "that is an original idea". I thought this was great and it was } \\
\text { indeed an original idea. Later, I found out that this was just the British way of refusing in a } \\
\text { respectful manner. It was heartbreaking in some moments (laughing)." (Employee F1) }\end{array}$ \\
\hline $\begin{array}{l}\text { 8. Clarify } \\
\text { communication and } \\
\text { understanding } \\
\text { variations }\end{array}$ & $\begin{array}{l}\text { "One's capabilities, experience, potential are the tools that need to be used for getting their attention, } \\
\text { for making them remember you and most importantly making them convinced that you might be } \\
\text { someone that might be of use at some point. This is the starting point. The more you continue to } \\
\text { communicate with these people, the more of a desired party you become, as they have the }\end{array}$ \\
\hline
\end{tabular}




\begin{tabular}{|c|c|}
\hline $\begin{array}{l}\text { Description: Learning about } \\
\text { the importance of giving } \\
\text { forward to the diaspora as a } \\
\text { way to initiate reciprocation }\end{array}$ & $\begin{array}{l}\text { perception that you can support them in some way. Once they cannot afford to lose you, the flow } \\
\text { has been created and the barriers have been removed." (Entrepreneur C) } \\
\text { "They [diaspora participants] are also great supporters for the business, these are the people that I } \\
\text { care about the most. They tell me what they want and I tell them what I have, this is how the trade } \\
\text { occurs. If they want something that I don't have ... I will have it next time. It is important to be } \\
\text { close to people, it helps being down to earth and it also help for the business so everyone wins."( } \\
\text { Entrepreneur A) } \\
\text { "I am approaching people in a very open way. When I know that a person might help me by sharing } \\
\text { something with me I first of all prove that my use of the information will not interfere with their } \\
\text { business activities. I also show that the other party will benefit from having me as a partner. I let } \\
\text { them know that I am a team player and they can expect reciprocal activities from me. It is important } \\
\text { to be supportive when they need it, this shows that I don't forget, which will help for the future." } \\
\text { (Entrepreneur C) } \\
\text { "Have you heard the Bulgarian proverb...it is an old one, it says 'A cooperative group can move } \\
\text { even a mountain', I think it summarizes it all. Here in the UK, we need to listen to each other, work } \\
\text { together while we may be competing [laughs], but not because we may like it but because this is part } \\
\text { of survival. And earlier newcomers recognize that this brings higher chances of survival; success } \\
\text { comes later." (Employee G1) }\end{array}$ \\
\hline $\begin{array}{l}\text { 9. Attempt to } \\
\text { overcome market } \\
\text { disorientation }\end{array}$ & $\begin{array}{l}\text { "We often talk with the members of the British Bulgarian Chamber of Commerce. The members of } \\
\text { the organization are extremely experienced. [...] These are people who have shown strengths and } \\
\text { capabilities that the market has accepted. Most of them are experts in doing business and they can } \\
\text { help with direct advice and share stories about what has happened when a company engaged a } \\
\text { particular strategy. Moreover, they have many business contacts with people from various spheres, } \\
\text { which can also benefit us as information does not flow directly. Talking with members enhances } \\
\text { referrals and linking to other parties, which creates a significant mechanism for transferring business } \\
\text { ideas and facilitates problem solving." (Entrepreneur L) } \\
\text { "I ask the business professionals from the Bulgarian club, there are not many owners there but the } \\
\text { members are smart people, energetic, working for big companies - marketing, accounting, finance, } \\
\text { logistics. They know their field, through them I now know a little of every field.... Getting fresh }\end{array}$ \\
\hline
\end{tabular}




\begin{tabular}{|c|c|}
\hline & $\begin{array}{l}\text { ideas always helps. They also know people, they connect me to others. We cooperate, they are also } \\
\text { among my clients ... I sometimes provide free food and drinks for their events, they sometimes } \\
\text { provide me with free help and advice." (Entrepreneur A) } \\
\text { "During the course we brainstorm and it was a very good way to generate personal ideas and also } \\
\text { get ideas from the other members and adapt to what might serve to my goals. Just finding friends } \\
\text { and contacts outside the borders of my business is enough to increase the idea generation." } \\
\text { (Entrepreneur F) }\end{array}$ \\
\hline $\begin{array}{l}\quad \text { 10. Verify market } \\
\text { knowledge } \\
\text { Description: Verifying the } \\
\text { relevance of accumulated } \\
\text { market knowledge and } \\
\text { competences }\end{array}$ & $\begin{array}{l}\text { "There are normal evolutionary forces that have changed what customers want and what companies } \\
\text { offer. As long as that pattern is occurring the business environment will continue to change. [...] } \\
\text { What differs are the efforts of the business owners to get ahead of their competitors in order to meet } \\
\text { the quickly changing needs of the markets. Due to this constant competition between owners, we } \\
\text { have enough work to assist them to reach their full potential and aspirations, but we also have } \\
\text { enough to learn. [...] Reflecting on personal acquaintances leads to gaining competences and } \\
\text { achieving higher local relevance." (Entrepreneur I) } \\
\text { "I just know [the areas where business improvement is necessary] because I am close to the } \\
\text { operations of the business and I follow all the changes in the economy. Also, just by following what } \\
\text { the newspapers write. If there is a major trend and all newspapers write how bad the situation is I } \\
\text { would not expect that many people will come to buy properties. Customers are very affected by the } \\
\text { media, which is why good publicity is very important." (Entrepreneur G) }\end{array}$ \\
\hline $\begin{array}{l}\text { 11. Verify management } \\
\text { operations } \\
\text { Description: Validating the } \\
\text { relevance of the business } \\
\text { practices towards other } \\
\text { businesses, employees, and } \\
\text { clients in order to maximize } \\
\text { efficiency }\end{array}$ & $\begin{array}{l}\text { "If we did not know how to plant our roots deep inside the business environment and extract all the } \\
\text { nutrients necessary for business enhancement and growth, that would have resulted in the poorest } \\
\text { business performance." (Entrepreneur I) } \\
\text { "Where it was not possible to get the information directly from the company, we looked elsewhere. } \\
\text { Many marketing companies had their clients listed on their websites, just as a way to encourage } \\
\text { other clients to join. We used that, we got in touch with some of their former clients and asked them } \\
\text { what kind of services they have been using and whether they are satisfied. This was enough to find } \\
\text { what the good are and the weak sides of our future, now current, competitors." (Entrepreneur B) }\end{array}$ \\
\hline
\end{tabular}




\begin{tabular}{|c|l|}
\hline & $\begin{array}{l}\text { "As part of my job, I am encouraged to attend regularly seminars and professional lectures. This } \\
\text { allows me to stay close to the field by learning from other more successful law professionals with } \\
\text { greater experience...they have experienced every little stone on the path we are walking on. Having } \\
\text { their advice on, for example, upcoming regulatory changes is often a shortcut which can reduce the } \\
\text { cost of running the business or improve our reputation among the clients. The right timing is very } \\
\text { important for our business." (Employee E1) }\end{array}$ \\
\hline $\begin{array}{l}\text { 12. Verify production } \\
\text { practices }\end{array}$ & $\begin{array}{l}\text { "I talk relatively often with some people I know through my involvement with the Bulgarian } \\
\text { community here. They are closer to the market here, so it is easier to talk to them rather than first } \\
\text { explaining the characteristics of the market to somebody else. This gives new perspectives, an } \\
\text { unbiased opinion. That word-of-mouth communication expands my knowledge about what clients } \\
\text { want and how I can serve their needs better, because customers are different in this country." } \\
\text { (Entrepreneur A) }\end{array}$ \\
$\begin{array}{l}\text { Description: Validating } \\
\text { prodice offering or } \\
\text { hearing from other network } \\
\text { incumbents }\end{array}$ & $\begin{array}{l}\text { "Participation in such organizations [British Bulgarian Chamber of Commerce] built reputation and } \\
\text { established various contacts to different business spheres and social circles. By increasing our } \\
\text { contacts to different companies, we get to know what marketing activities they have engaged in and } \\
\text { whether these activities were successful. Therefore, if we have a client from the same industry in the } \\
\text { future we would know what might work and what will not. This is very valuable!" (Entrepreneur B) }\end{array}$ \\
\hline
\end{tabular}


Table 3

Initiation Cycle: Divestment and Pioneering of Knowledge

\begin{tabular}{|c|c|}
\hline $\begin{array}{c}\text { Label (first-order } \\
\text { categories) }\end{array}$ & Representative Quotes \\
\hline $\begin{array}{l}\quad \text { 13. Restructure } \\
\text { knowledge } \\
\text { Description: Revising } \\
\text { existing knowledge related } \\
\text { to operations and tactics for } \\
\text { competitiveness }\end{array}$ & $\begin{array}{l}\text { "At the very beginning it was only the Bulgarian immigrants that I was selling to. That is how the } \\
\text { business idea developed and that is how the business itself developed. Later, I figured out that the } \\
\text { bills need to be paid and it is risky to sell only to Bulgarians. Of course, there were locals that were } \\
\text { buying as well but their number was quite limited. At first I had no idea how to attract the locals, } \\
\text { they were so distant for me although I was living among them. I had to find a solution how to } \\
\text { approach them and I did. I offered what was trendy, organic products, natural teas, and natural herbs. } \\
\text { They started coming, they looked around, then came back and bought more and more often. Now I } \\
\text { know many of the locals who are regular clients." (Entrepreneur A) } \\
\text { "After the financial crunch we need to invest much more in marketing and branding and people care } \\
\text { not only about paying less, but also about higher quality. This makes it difficult. They also see the } \\
\text { property as an investment not only as a holiday home. It is getting harder because a few years ago } \\
\text { our target market was middle-income people; however, now because of the shrinking incomes we } \\
\text { needed to redefine our target market, which now includes more affluent customers. Therefore this } \\
\text { really requires redefining our objectives and marketing strategies." (Entrepreneur G) } \\
\text { "We realize that it is hard to survive in the business world. It is very dynamic and everything } \\
\text { changes very quickly. For that reason we constantly review and redefine our business goals. It is not } \\
\text { as easy as it sounds. The decision-support information, on which we rely to adapt our vision and } \\
\text { business moves in order to meet the foreign environment requirements, comes from our analysis." } \\
\text { (Entrepreneur H) }\end{array}$ \\
\hline $\begin{array}{l}\text { 14. Abandon knowledge } \\
\text { Description: Disposing of } \\
\text { knowledge that has proved } \\
\text { ineffective }\end{array}$ & $\begin{array}{l}\text { "Only after disposing of the illusion that what we know from before can make us competitive here } \\
\text { can we really concentrate on developing what can serve us well. Once I realized that, my company } \\
\text { became a more active participant in the market." (Entrepreneur L) }\end{array}$ \\
\hline
\end{tabular}




\begin{tabular}{|c|c|}
\hline & $\begin{array}{l}\text { "We want to sell exclusive wines, something that people cannot just find in the local Tesco or other } \\
\text { mainstream shops, so this requires that we are careful in what we advertise and in what we import. } \\
\ldots \text { [Every] bottle makes a statement not only about our clients but about us as well. It happened once } \\
\text { that we needed to stop importing a particular series that could be found in the beverages corner of } \\
\text { mainstream shops. We cannot compete with these guys [referring to big supermarkets] so have } \\
\text { learnt to adopt market screening strategies." (Employee/ Business partner H1) }\end{array}$ \\
\hline $\begin{array}{l}\text { 15. Develop new } \\
\text { capabilities by } \\
\text { knowledge } \\
\text { recombination }\end{array}$ & $\begin{array}{l}\text { "We [diaspora members] all act very proactively, explore different opportunities, improve the } \\
\text { efficiency of the already existing business models. It all happens naturally, I think that our } \\
\text { familiarity with several countries gives us some advantage." (Entrepreneur A) } \\
\text { "Combining the ordinary marketing techniques with the most innovative - new to the average } \\
\text { business owner - techniques is what makes us competitive in this environment saturated by } \\
\text { marketing companies." (Entrepreneur B) } \\
\text { "Our primary sources of new ideas are our current clients, in addition to past clients. Once per } \\
\text { month, the manager asks us to talk to them, to send them questionnaires regularly etc. He believes } \\
\text { our relationship with them is a hidden gem, a special capability, which allows us to stay ahead of the } \\
\text { competition." (Employee G1) }\end{array}$ \\
\hline $\begin{array}{l}\text { 16. Form autonomous } \\
\text { specialization } \\
\text { competencies } \\
\text { Description: Recognizing } \\
\text { the need for accumulating } \\
\text { new knowledge from outside } \\
\text { and/or the formation of new } \\
\text { relations }\end{array}$ & $\begin{array}{l}\text { "If we do not possess the right level of expertise, we go to the market to buy some. Literally, we buy } \\
\text { knowledge and proficiency. We cannot afford to keep a person who we need only twice a year. } \\
\text { Moreover, the people we are looking for are experts in their fields and they are expensive. Expertise } \\
\text { has always been highly valued so we purchase only part of the time of that specialist and build up } \\
\text { the rest of the project based on the ideas and information we have acquired or that we possess in- } \\
\text { house. Such free agent consultants often work for four or even five companies, advising them. It is } \\
\text { inefficient, too expensive for a single company to afford such high ranked specialists, but we still } \\
\text { benefit from the innovative thinking of such acknowledged experts rather than competing with them. } \\
\text { In that way we can provide our clients with solutions for their business, solutions that would have } \\
\text { cost them a fortune if they were to hire all the narrow experts that we communicate with." } \\
\text { (Entrepreneur I) } \\
\text { "We spent a lot of time online, researching company profiles... even calling companies and } \\
\text { pretending to be potential clients, who are interested in knowing more about the companies" }\end{array}$ \\
\hline
\end{tabular}


activities. We talked to different people working in marketing companies, we went to internet marketing forums. We categorized the results that we got and found our niche, our specialty. At that point not many people have capitalized on Google Places. We decided to get involved with local search engine optimization for all the businesses that might be interested, but small companies being our focus." (Entrepreneur B)

"Some others have been doing that [specializing in real estate] but I decided that I can do this [specializing in real estate] rather than leaving the pie to competition. It was crucial to find a way to introduce the Bulgarian brand, the Bulgarian tourism in general.” (Entrepreneur G) 
Figure 1

Data Structure \& Reduction

First-order categories

1. Overcome social disorientation

2. Realize disrupted market integration capacity

3. Gain knowledge regarding intangible barriers

4. Absorb norms, codes of conduct (reflexivity)

5. Extracting resources from personal experiences

6. Engage in efficient management of the countryspecific knowledge sources and flows

7. Decrease cultural distance by learning host country's rules and regulations

8. Clarify communication and understanding variations

10. Market knowledge verification

11. Management operations verification

13. Knowledge restructuring

14. Knowledge abandonment

15. Develop new capabilities by knowledge recombination

16. Form autonomous specialization competencies

Source: Adapted from Corley \& Gioia (2004)
Second-order themes Aggregate dimensions
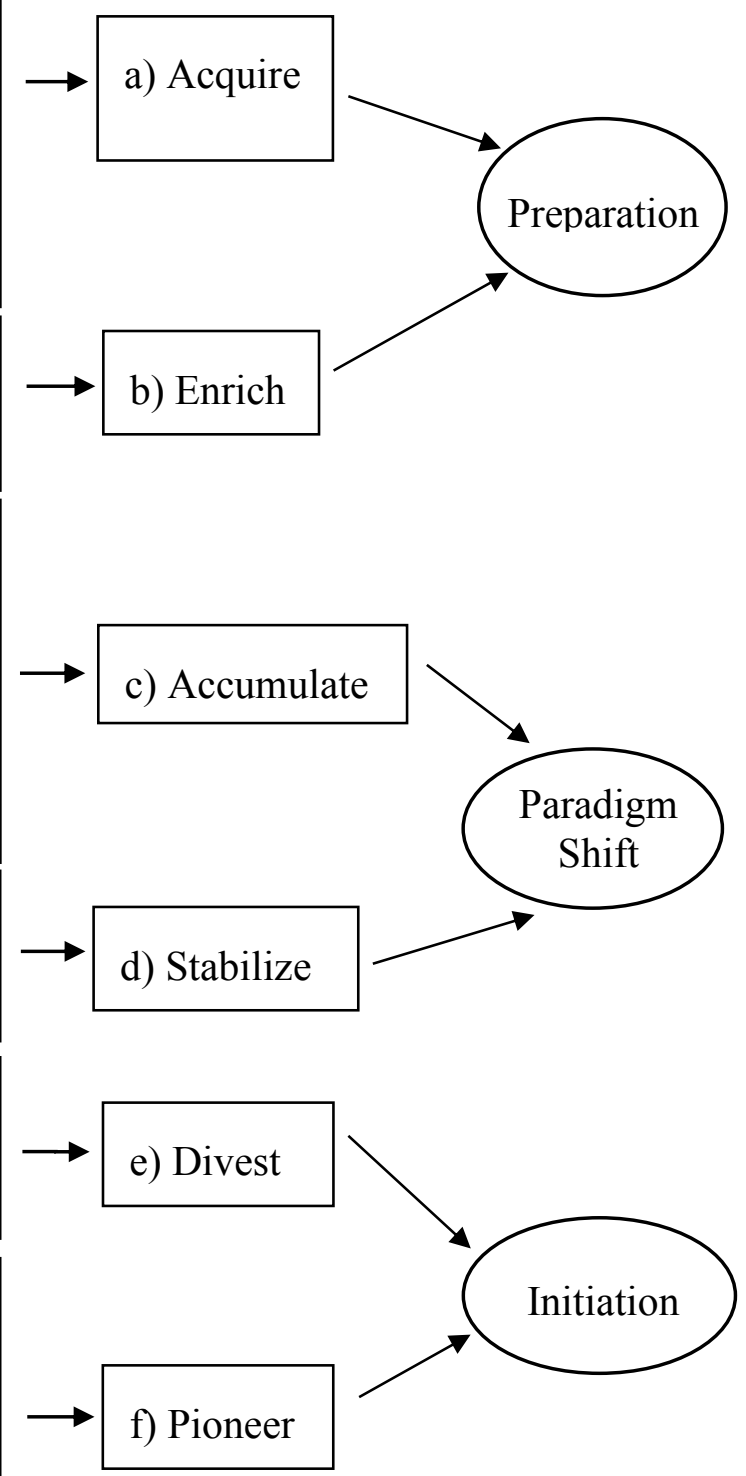
Figure 2

Sequence of processes and associated tactics

\begin{tabular}{|c|c|c|c|c|}
\hline \multicolumn{5}{|c|}{ Processes } \\
\hline $\begin{array}{l}\text { - Overcoming } \\
\text { disorientation } \\
\text { - Supporting cultural } \\
\text { events }\end{array}$ & $\begin{array}{l}\text { - Developing desire to } \\
\text { enter a community of } \\
\text { practice }\end{array}$ & $\begin{array}{l}\text { - Acquire and enrich } \\
\text { knowledge }\end{array}$ & $\begin{array}{l}\text { - Accumulate and } \\
\text { stabilize knowledge }\end{array}$ & $\begin{array}{l}\text { - Knowledge divesting } \\
\text { and pioneering }\end{array}$ \\
\hline OUTSIDERSHIP & $\begin{array}{l}\text { JOINING DIASPORA } \\
\text { CULTURAL CIRCLE }\end{array}$ & $\frac{\frac{\text { JOINING }}{\text { COMMUNITY OF }}}{\frac{\text { BUSINESS }}{\text { PRACTICE }}}$ & $\frac{\frac{\text { GAINING }}{\text { NETWORK }}}{\text { EMBEDDEDNESS }}$ & INSIDERSHIP \\
\hline $\begin{array}{l}\text { Desire to establish } \\
\text { business relationships }\end{array}$ & $\begin{array}{l}\text { - Supporting cultural } \\
\text { events } \\
\text { - Preserving cultural } \\
\text { belongingness } \\
\text { - Gaining exposure to } \\
\text { ethnic community }\end{array}$ & $\begin{array}{l}\text { - Absorbing norms and } \\
\text { codes of conduct } \\
\text { - Managing country- } \\
\text { specific knowledge }\end{array}$ & $\begin{array}{l}\text { - Learning host } \\
\text { country's rules and } \\
\text { regulations } \\
\text { - Verifying relevance } \\
\text { of practices } \\
\text { - Verifying market } \\
\text { knowledge }\end{array}$ & $\begin{array}{l}\text { - Develop new } \\
\text { capabilities by } \\
\text { recombination } \\
\text { - Knowledge } \\
\text { reconstruction }\end{array}$ \\
\hline
\end{tabular}

\section{$\underline{\text { Tactics }}$}

